\title{
Spatiotemporal Variability of Lightning Flash Distribution over Sri Lanka
}

\author{
U.G. Dilaj Maduranga ${ }^{1, a}$, Mahesh Edirisinghe ${ }^{1, b^{*}}$ and L. Vimukthi Gamage ${ }^{2, c}$ \\ ${ }^{1}$ Department of Physics, University of Colombo, Colombo 03, Sri Lanka \\ ${ }^{2}$ Department of Agriculture, Sri Lanka School of Agriculture, Agunukolapelessa, Sri Lanka \\ adilajmaduranga@gmail.com, bmahesh@phys.cmb.ac.lk, cleenath.wymukthi@gmail.com
}

\section{Keywords: LIS, Lightning protection, TRMM, Lightning flash density}

\begin{abstract}
The variation of the lightning activities over Sri Lanka and surrounded coastal belt $\left(5.75^{\circ} \mathrm{N}-\right.$ $10.00^{\circ} \mathrm{N}$ and $79.5^{\circ} \mathrm{E}-89.00^{\circ} \mathrm{E}$ ) was studied using lightning flash data of Lightning Imaging Sensor (LIS) which was launched in November 1997 for NASA's Tropical Rainfall Measuring Mission (TRMM). The LIS data for the period of 1998 to 2014 were considered for this study. The spatial and temporal variation of lightning activities was investigated and respective results are presented. The diurnal variation over the studied area presents that maximum and minimum flash count recorded at 1530-1630 Local Time (10-11UTC) and 0530-0630LT (00-01UTC) respectively. Maximum lightning activities over the observed area had occurred after the 1330LT (08UTC) in every year during the considered time period. The seasonal variation of the lightning activities shows that the maximum lightning activities happened in first inter monsoon season (March to April) with 30.90\% total lightning flashes and minimum lightning activities recorded in northeast monsoon season (December to February) with $8.51 \%$ of total lightning flashes. Maximum flash density was observed as $14.37 \mathrm{fl} \mathrm{km}^{-2} \mathrm{year}^{-1}$ at $6.98^{0} \mathrm{~N} / 80.16^{0} \mathrm{E}$ in first inter monsoon season. These seasonal lighting activities are in agree with seasonal convective activities and temperature variation base on propagation of Intra-Tropical Convection Zone over the studied particular area. Mean monthly flash count presents a maximum in the month of April with $29.12 \%$ of lightning flashes. Variation pattern of number of lightning activities in the month of April shows a tiny increment during the time period of 1998 to 2014. The maximum annual flash density of $28.09 \mathrm{fl} \mathrm{km}^{-2} \mathrm{yr}^{-1}$ was observed at $6.98^{0} \mathrm{~N} / 80.17^{0} \mathrm{E}$. The latitudinal variation of the lightning flash density was depicted that extreme lightning activities had happened at the southern part of the county and results show that there was a noticeable lack of lightning activities over the surrounded coastal belt relatively landmass.
\end{abstract}

\section{Introduction}

Lightning is one of the oldest observed natural phenomena on the earth. A large thunderstorm can produce more than hundreds of lightning flashes within a very small time duration. It has a potential to cause serious damages to both the living beings and properties.

A comprehensive study of the lightning activities of a country is an important factor to mitigate lightning hazards and designing of a lightning protection system at a particular location [1]. Furthermore, awareness of the community about lightning hazards and time periods of intense lightning activities are significant factors that can be launched to minimize these types of unpredictable natural destructive hazards. Most of the lightning activities which taking place on the earth's atmosphere are confined to tropical regions [2]. Therefore, in general, lightning activities over Sri Lanka and its surrounded coastal belt are relatively higher than other regions. The previous studies in this field have reported that the characteristics of lightning flashes depend on number of parameters such as longitude, latitude, altitude, soil content, topography and vegetation of the region etc... [3].

Lightning activities which occur over the lands of Sri Lanka are generally harmful to different areas of the country. Mainly, reported lightning deaths and serious injuries in the country have been increased within last few years according to data of the Metrological Department of Sri Lanka. Furthermore, damages to properties, impacts and effects on power and communication lines and conflagrations happening over the country are the other hazardous of lightning. On the other hand, Sri Lanka is an island, located in tropical region in South Asia. Therefore, study about frequent 
lightning incidents is also important to understand thoroughly before predicting the high lightning active regions and time period over the island and its surrounded coastal belt. Furthermore, lightning mapping system can be used to minimize the harmful effects of lightning by providing early warnings of possible hazardous areas.

Moreover, most of the countries have a tendency to collect the lightning data over their countries. According to previous studies, location base lightning data were used to investigate the properties of lightning parameters in Sri Lanka [4]. Therefore, lightning data has proved to be a powerful tool to get significant parameters such as convection strength and estimation of convective rainfall [5,6]. Moreover, Tropical Rainfall Measurement Mission (TRMM) had begun to collect the lightning data in 1990 [7]. The Lightning Imaging Sensor (LIS) was a space-based instrument used to detect the distribution of lightning activity in TRMM [8]. This instrument successfully operated over seventeen years. LIS on TRMM satellite observed lightning activities over the tropical region bounded $35^{\circ} \mathrm{N}-35^{0} \mathrm{~S}$ and it travelled a distance of seven kilometers in every second. This data consist of amount, rate and radiant energy of lightning flashes etc... in both day and night. Henceforth this data can be used to precisely study the mesoscale phenomena such as storm convection, dynamics and microphysics [9].

Such lightning activities over Sri Lanka had been analyzed previously [10] using LIS on TRMM satellite data in the period from 1998 to 2006 and Jayawardana [11] had analyzed about lightning activities over Sri Lanka using LIS on TRMM satellite data in the period from 1998 to 2012. Orville [12] and Chaudhari [13] had analyzed and designed the lightning density maps, using the cloud-toground (CG) lightning flash data of National Lightning Detection Network (NLDN) and LIS on TRMM satellite data in USA and Indian subcontinent respectively. Moreover, variation trend of the lightning activities over Sri Lanka have analyzed in [14] using LIS on TRMM satellite data in the period from 1998 to 2014. The reported study in this paper considered relevant data in the period from 1998 to 2014 which was obtained from TRMM for the analysis of spatiotemporal variability of lightning flash distribution over Sri Lanka and its surrounded coastal belt. It was analyzed and visualized by using the Geographic Information System (GIS) software (ArcGIS 10.1 version) and ultimately estimated the maximum and minimum flash density for relevant areas, time periods and other important relevant information related to lightning hazards of the country.

\section{Data Collection}

LIS is an instrument of NASA Earth Observing System (EOS) on the TRMM platform designed to obtain and investigate the distribution and variability of total lightning between $\pm 35^{\circ}$ in latitudes. It could observe a $600 \mathrm{~km} \times 600 \mathrm{~km}$ area of the earth with a spatial resolution of between $3 \mathrm{~km}$ to $6 \mathrm{~km}$ and could monitor the individual storm for lightning activities for almost 80 seconds as it passes overhead during both day and night [9]. The LIS on TRMM had estimated the time of occurrence, radiant energy and location of the lightning events with detection efficiency from $69 \%$ near noon to $88 \%$ in the night [15]. It was passing over Sri Lanka twice per day which means 160 s day $^{-1}$ and normalizing factor is used to calculate the lightning flash density as stated in [11]. For this study, total lightning activities which include cloud-to-cloud, intra-cloud, and cloud-to-ground lightning data of period from 1998 to 2014 over Sri Lanka and surrounded coastal belt which cover $5.75^{\circ} \mathrm{N}-10.00^{\circ} \mathrm{N}$ and $79.50^{\circ} \mathrm{E}-89.00^{\circ} \mathrm{E}$ were considered which were obtained from TRMM [7].

\section{Data Analysis}

Maier [16] found that flash density may vary by an order of magnitude over distance of 20$30 \mathrm{~km}$. Therefore, the data were organized into respective $0.2^{0} \times 0.2^{0}$ latitude and longitude grids. Then, the organized data were used to depict the diurnal lightning activities and latitudinal variation of the lightning activities over the selected particular area seasonally and annually. According to annual rainfall profile of Sri Lanka, there are two monsoon sessions and two inter monsoon seasons, namely southwest monsoon season (May to September), northeast monsoon season (December to February), first inter monsoon season (March to April) and second inter monsoon season (October to 
November). The calculations of seasonal variation of the lightning activities were based on above four monsoon seasons. Ultimately, maximum and minimum flash densities were obtained seasonally and annually. Results were used to investigate the highly lightning active regions over Sri Lanka and its surrounded coastal belt. Existing 25 administrative districts of Sri Lanka have been taken for consideration, to analyze the highly active lightning areas.

\section{Results and Discussion}

Spatial and temporal distribution of the lightning activities over Sri Lanka and its surrounded coastal belt are presented diurnally, seasonally and annually covering the period of 17 years from 1998 to 2014.

\section{Diurnal variation of the lightning activity}

Diurnal variation of the lightning activity which based on the occurrence of lightning flashes over Sri Lanka and surrounded coastal belt depicts in the Fig. 1(a). It indicates that maximum lightning activities had occurred in between 1530-1630 Local Time (10-11UTC). About 19.47\% lightning activities of a day had recorded during this time period. Minimum lightning activities had occurred in between 0530-0630LT (00-01UTC). Both variation patterns of number of lightning flashes and percentages of 17 years of lightning flash data were symmetrically distributed through the maximum and show a binomial distribution pattern. Jayanthiran [10] had reported a same time period of maximum lightning activities occurred during a day using data in the period from 1998 to 2006. However, it had been noted that, although time of the occurrence of the maximum lightning activities was same in both studies, number of lightning activities had been increased by $8.17 \%$, with the same distribution pattern. But, Jayawardana [11] had not reported about the diurnal variation of lightning activities over the country. Although the variation trend of average lightning activities of 17 years (1998-2014) showed maximum lightning activities occurred in the time period of 1530$1630 \mathrm{LT}$, some dramatically changes of maximum lightning active time periods show in year wise separation graphs of lightning data in Fig. 1(b). According to the Fig. 1(b), maximum lightning activities had recorded in time period of 1330-2130LT (08-16UTC) in different years. But, lightning activities in late of the noon (after the 1330LT) had fluctuated relative to the variation trend of the average of the lightning data of 17 years mostly due to the result of solar forcing. The preceding results suggest that variation of the incoming solar radiation over the tropical region causes to diurnal convection cycle, which peaks at local noon [17]. Therefore, this solar radiation input is sufficient to heat the surface air layer of the earth and density of air layer is decreased and the atmosphere become unstable. It causes to form cumulonimbus cloud on sky. Formation of thunderstorm and lightning activities may occur over the land at local noon.
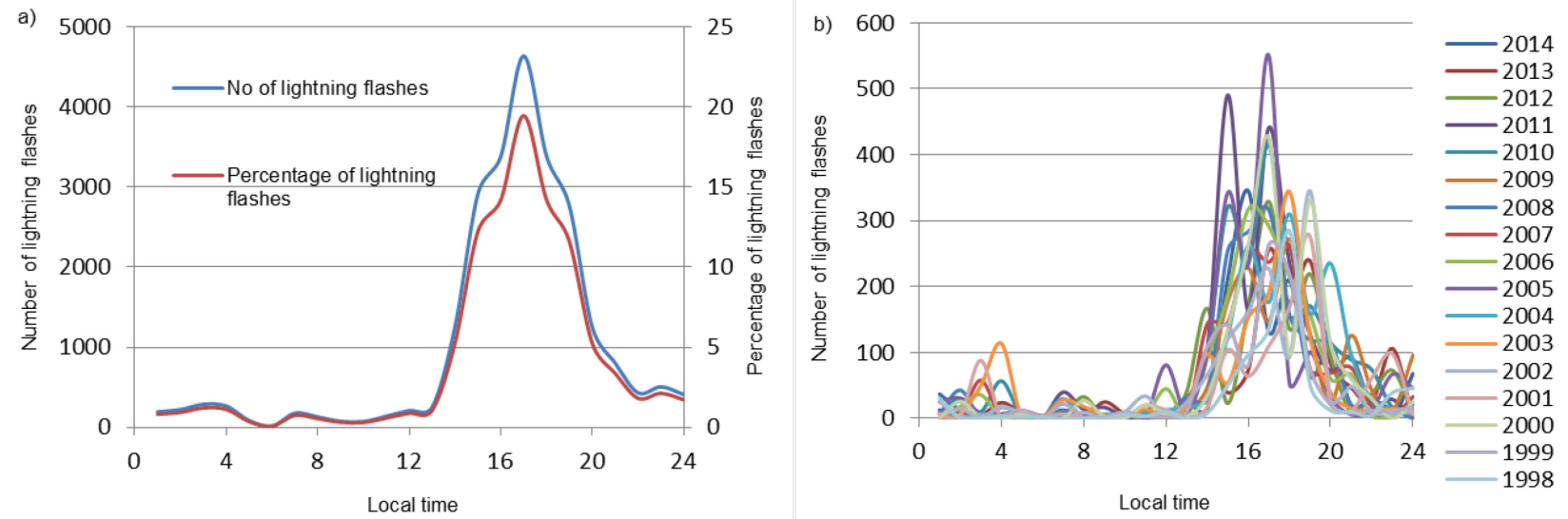

Figure 1. Lightning data which were obtained from LIS on TRMM observations from 1998 to 2014 (a) Average diurnal variation of lightning flashes; (b) Diurnal variation in year wise. 


\section{Latitudinal variation of the lightning activity}

In this section, latitudinal variation of the lightning activities over Sri Lanka and its surrounded costal belt had been studied in both seasonally and annually in the period from 1998 to 2014. Climate of Sri Lanka experienced during 12 months period can be characterized into monsoon period as explained in the previous and following study base on its seasonal and annual variation of the lightning activities.

\section{First inter monsoon season (March-April)}

Fig. 2(a) depicts average latitudinal variation of the lightning flash density for the period of 1998-2014 during first inter monsoon season over Sri Lanka and surrounded coastal belt. Accordingly, minimum number of lightning activities showed in northern latitude range of the country and maximum flash density of $4.43 \mathrm{fl} \mathrm{km}^{-2} \mathrm{month}^{-1}$ had recorded in the region between $6.95^{0} \mathrm{~N}$ and $7.15^{\circ}$ N. Fig. 2(b) shows the zonal average variation of lightning flash density of 17 years in first inter monsoon season. In most of the years, maximum zonal average of the lightning flash density had recorded in between $6.95^{\circ} \mathrm{N}$ and $7.15^{\circ} \mathrm{N}$. But, in 2014, $6.31 \mathrm{fl} \mathrm{km}^{-2} \mathrm{month}^{-1}$ had recorded in between $7.55^{\circ} \mathrm{N}$ and $7.75^{\circ} \mathrm{N}$. However, according to the Fig. 2(b), most of the lightning activities had occurred in between $6.2^{\circ} \mathrm{N}$ and $8.2^{0} \mathrm{~N}$ during this season. Fig. 3(a) describes the spatial variation of the lightning flash density over Sri Lanka and surrounded coastal belt for first inter monsoon season. Lightning flash density is depicted in number of flashes per square kilometer in year with spatial resolution of $0.2^{0} \times 0.2^{0}$ latitude and longitude. The maximum flash density of $14.37 \mathrm{fl} \mathrm{km}^{-2} \mathrm{year}^{-1}$ observed at $6.98^{\circ} \mathrm{N} / 80.16^{\circ} \mathrm{E}$ in this monsoon season. Generally, more lightning activities had occurred over the south-western slope of the country and it has clustered into its Gampaha $\left(7.0831^{0} \mathrm{~N} / 80.0144^{0} \mathrm{E}\right)$ and Kegalle $\left(7.2513^{\circ} \mathrm{N} / 80.5464^{0} \mathrm{E}\right)$ administrative districts. Dominant causes for the above described variation pattern of lightning activities could be described using the movement of Inter-Tropical Convergence Zone (ITCZ). Specially, ITCZ is located between $5^{0} \mathrm{~N}$ and $5^{0} \mathrm{~S}$ from March to April. Therefore, sunshine directly hits into southern part of the Indian Ocean relative to Sri Lanka. During this period, formation of the thunder clouds is generally thermally controlled. Thunderstorms and heavy convections may occur during the afternoon hours over southern area of the country [17]. It is important to mention that total monthly lightning flash density was increased by $16.67 \%$ during the first inter monsoon season relative to value reported in [11]. Moreover, an about $79.12 \%$ increment and a slight change of latitude range which occurred more lightning activities were showed details in [10]. Furthermore, Fig. 3(b) depicts the spatial variation of the lightning flash density with maximum flash density, $100.41 \mathrm{fl} \mathrm{km}^{-2}$ year ${ }^{-1}$ at $7.91^{0} \mathrm{~N} / 80.15^{0} \mathrm{E}$ during the first inter monsoon season in 2014, which has been recorded as the maximum zonal average value.
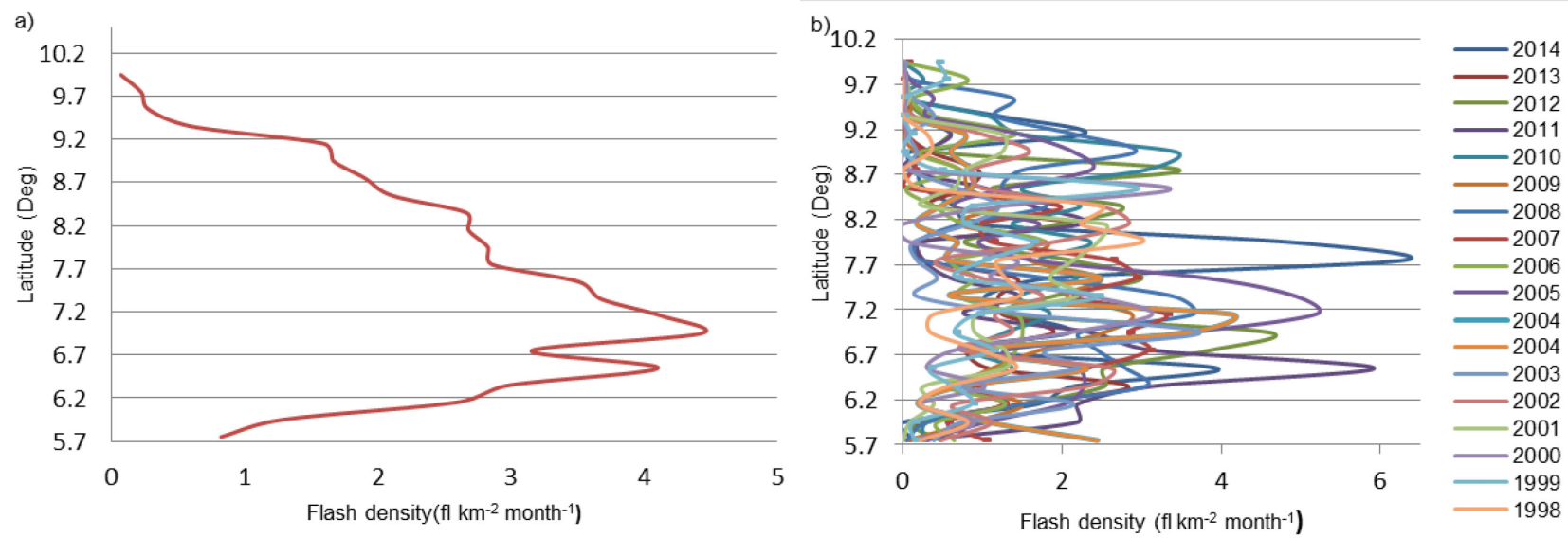

Figure 2. Average variation of flash density in first inter monsoon season over Sri Lanka in the period of 1998-2014 (a) Average latitudinal variation of lightning flash density; (b) Zonal variation of lightning flash density in year wise. 

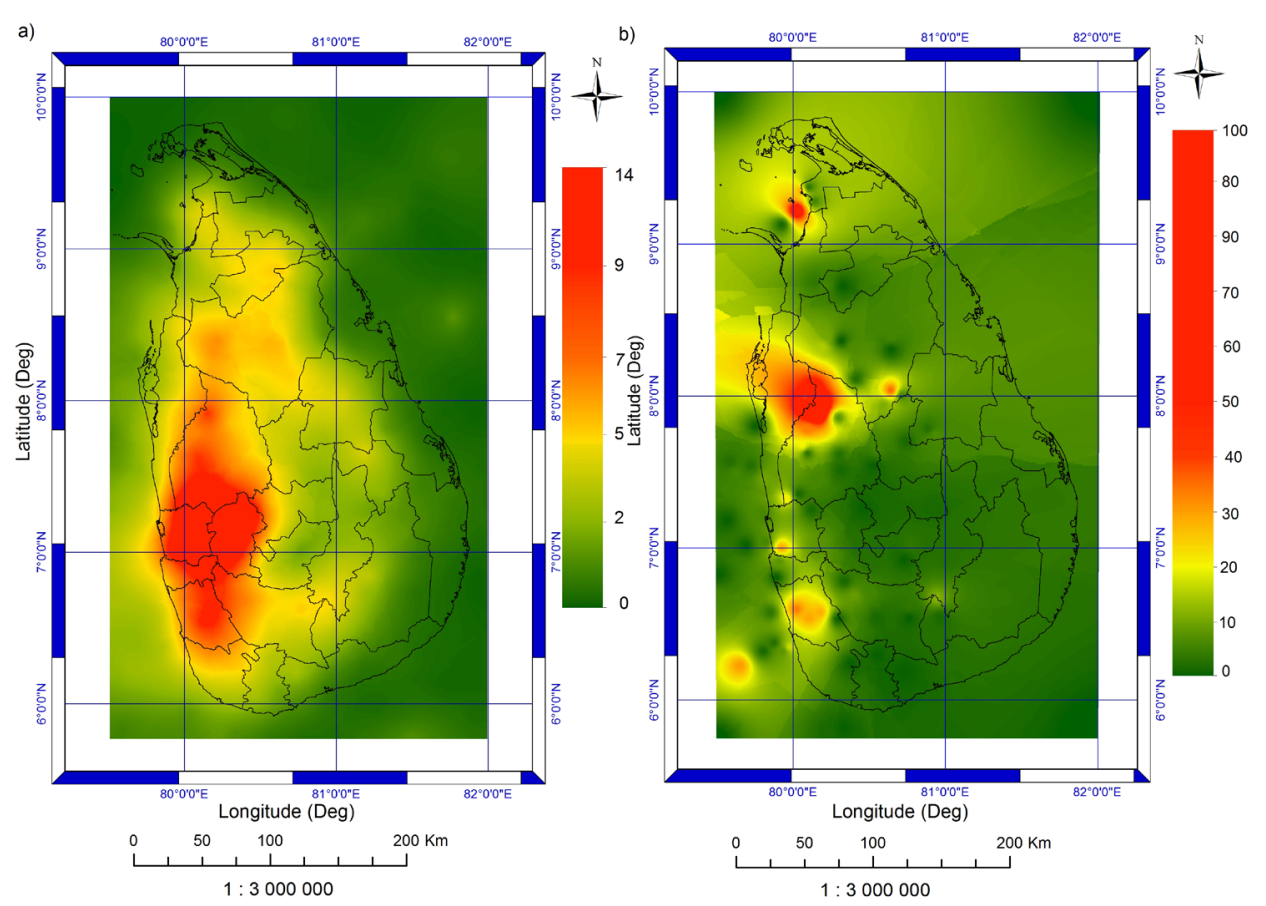

Figure 3. Spatial variation of the lightning flash density in first inter monsoon season over Sri Lanka in the period of 1998-2014 (a) Average spatial variation of the lightning flash density (b) Spatial variation of the lightning flash density in 2014.

\section{Southwest monsoon season (May - September)}

Fig. 4(a) describes the average latitudinal variation for lightning flash density over Sri Lanka and its surrounded coastal belt in the period from 1998 to 2014 for the southwest monsoon season. As it can be seen in Fig. 4(a), the maximum lightning flash density of $2.99 \mathrm{fl} \mathrm{km}^{-2} \mathrm{month}^{-1}$ occurs between $6.75^{\circ} \mathrm{N}$ and $6.95^{\circ} \mathrm{N}$ in this monsoon season. It could be observed that the lightning activities in between the region of latitudes $6.70^{\circ} \mathrm{N}$ and $7.20^{\circ} \mathrm{N}$ of Sri Lanka were higher than in the region of other latitudes. The zonal average variation of lightning flash density of 17 years in southwest monsoon season is presented in Fig. 4(b). Accordingly, the latitude range of the maximum value of the zonal average variation of lightning flash density was changed in every year. In 2000, maximum value of zonal average variation of lightning flash density showed in between $8.35^{\circ} \mathrm{N}$ and $8.55^{0} \mathrm{~N}$ than the other years of considered. Although zonal average value of monthly flash density is very low, latitude range with abundant lightning activities is approximately same as the reported information in [10]. According to Fig. 5(a), maximum value of lightning flash density is $9.58 \mathrm{fl} \mathrm{km}^{-2} \mathrm{year}^{-1}$, occurred at $6.79^{0} \mathrm{~N} / 81.33^{\circ} \mathrm{E}$ in southwest monsoon season which is closed to southwest area of Ampara $\left(7.2318^{0} \mathrm{~N} / 81.6473^{0} \mathrm{E}\right)$ district in eastern province of the Sri Lanka. The maximum value of lightning flash density had been decreased by about $25 \%$ relative to reported details in [11] during the southwest monsoon season and about $62.11 \%$ of increment of lightning activities showed result in [10]. Above variation of lightning activities could be explained using ITCZ. In this period, position of the ITCZ shift to north latitudes and sun directly overhead to the topic of cancer in northern hemisphere on about $22^{\text {nd }}$ of June [18]. It affects to Indian subcontinent by increasing land temperature and decreasing air pressure over the Indian subcontinent. In this season, due to southwest winds push the thunder clouds towards the northwest of the country and it may be caused to increase the lightning activities in above mention areas. Furthermore, Fig. 5(b) shows the spatial variation of the lightning flash density during the southwest monsoon season in 2000, which has been recorded as the maximum zonal average value. It shows that maximum value of lightning flash density is $53.55 \mathrm{fl} \mathrm{km}^{-2} \mathrm{year}^{-1}$, occurred at $8.96^{0} \mathrm{~N} / 80.43^{\circ} \mathrm{E}$. 

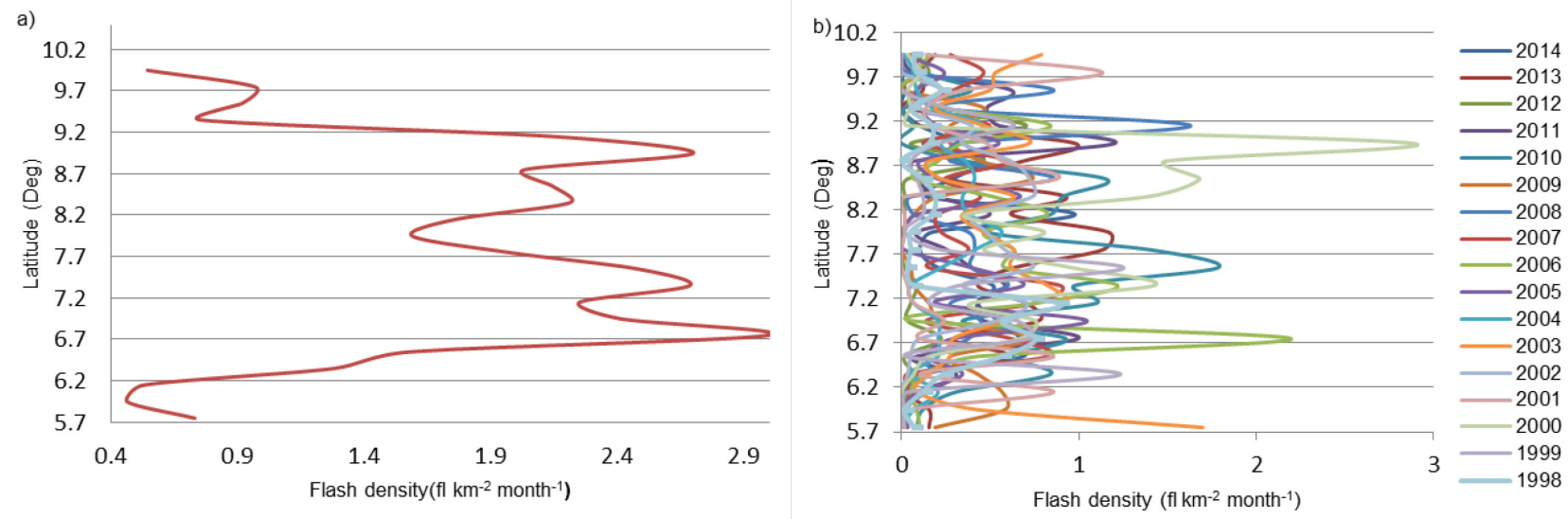

Figure 4. Average variation of flash density in Southwest monsoon season over Sri Lanka in the period of 1998-2014 (a) Average latitudinal variation of lightning flash density; (b) Zonal average variation of lightning flash density in year wise.
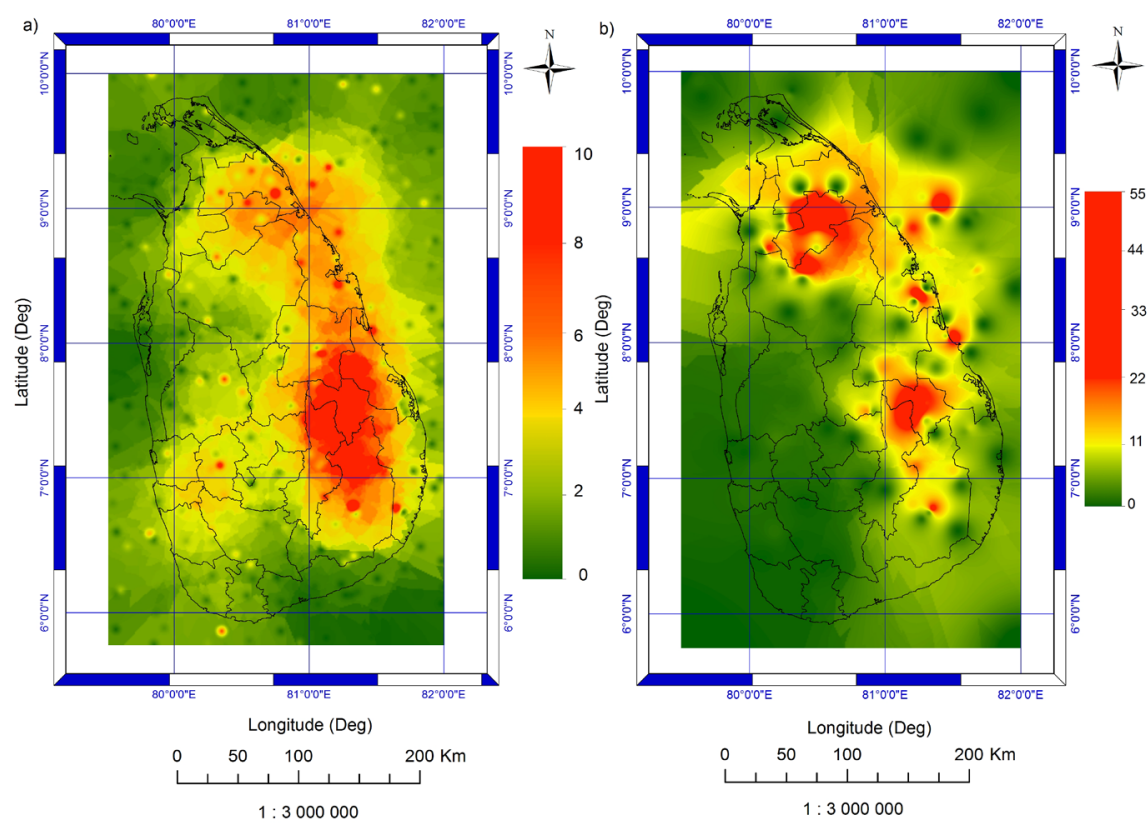

Figure 5. Spatial variation of the lightning flash density in Southwest monsoon season over Sri Lanka in the period of 1998-2014 (a) Average spatial variation of the lightning flash density (b) Spatial variation of the lightning flash density in 2000.

\section{Second inter monsoon season (October-November)}

Average latitudinal variation of lightning activity over Sri Lanka and surrounded coastal belt for second inter monsoon depicts in Fig. 6(a). In the second inter monsoon season, more lightning activities occurred in between latitude from $6.95^{\circ} \mathrm{N}$ to $7.15^{\circ} \mathrm{N}$. The maximum value of the lightning flash density in this monsoon season over Sri Lanka was $1.96 \mathrm{fl} \mathrm{km}^{-2} \mathrm{month}^{-1}$. Southern area of the country having more lightning activities compares with its northern area. But, an increment of an about 59\% monthly lightning activities is interpreted in this paper with reported values in [10]. The zonal average variation of lightning flash density of 17 years in second inter monsoon season is illustrated in Fig. 6(b). Maximum value of zonal average of lightning flash density, $4.63 \mathrm{fl} \mathrm{km}$ - year- $^{-}$ ${ }^{1}$ was recorded in between $7.35^{\circ} \mathrm{N}$ and $7.55^{\circ} \mathrm{N}$ in 2006 and normally, high degree of the lightning activities occurred in between $6.55^{\circ} \mathrm{N}$ and $8.35^{\circ} \mathrm{N}$. According to map of spatial variation of lightning activities in second-inter monsoon season which shown in Fig. 7(a), the maximum flash density of $5.97 \mathrm{fl} \mathrm{km}^{-2}$ month $^{-1}$ observed at $7.07^{0} \mathrm{~N} / 80.25^{0} \mathrm{E}$ which is in the southern area of Sri Lanka. Furthermore, maximum lightning flash density observed in this study relatively decreases approximately by $34 \%$ to the values reported in [11] and about $59.80 \%$ increment was indicated as per the values reported in [10]. Though more lightning activities were restricted to Gampaha 
$\left(7.0873^{\circ} \mathrm{N} / 80.0144^{0} \mathrm{E}\right), \quad$ Kagalle $\left(7.2513^{0} \mathrm{~N} / 80.3464^{\circ} \mathrm{E}\right)$ and Colombo $\left(6.9271^{0} \mathrm{~N} / 79.8612^{0} \mathrm{E}\right)$ administrative districts, southern and northern provinces in the country show low lightning activities. Those variations of lightning activities may be associated with movement of ITCZ over the county. Specially, ITCZ moves towards the southern hemisphere from September and influence of the depression and cyclones in the Bay of Bengal is common during this monsoon season [17-18]. Under such condition, the whole country experiences strong winds and widely spread rain. In the afternoon hours, thermally induced convective thunderstorms occur over the earlier mentioned areas. Moreover, Fig. 7(b) illustrates the spatial variation of the lightning flash density during the second inter monsoon season in 2006, which has been recorded as the maximum zonal average value. It shows that maximum value of lightning flash density is $49.04 \mathrm{fl} \mathrm{km}^{-2} \mathrm{year}^{-1}$, occurred at $7.63^{0} \mathrm{~N} / 80.45^{0} \mathrm{E}$.
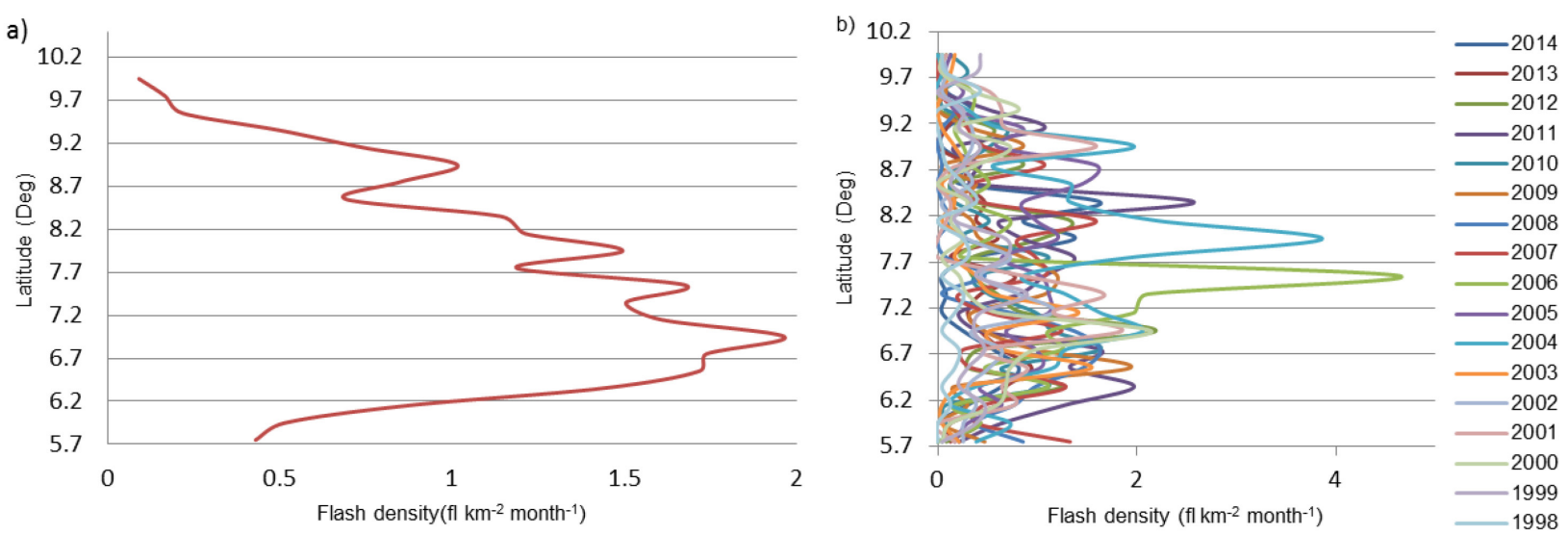

Figure 6. Average variation of flash density in second inter monsoon season over Sri Lanka in the period of 1998-2014 (a) Average latitudinal variation of lightning flash density; (b) Zonal average variation of lightning flash density in year wise.
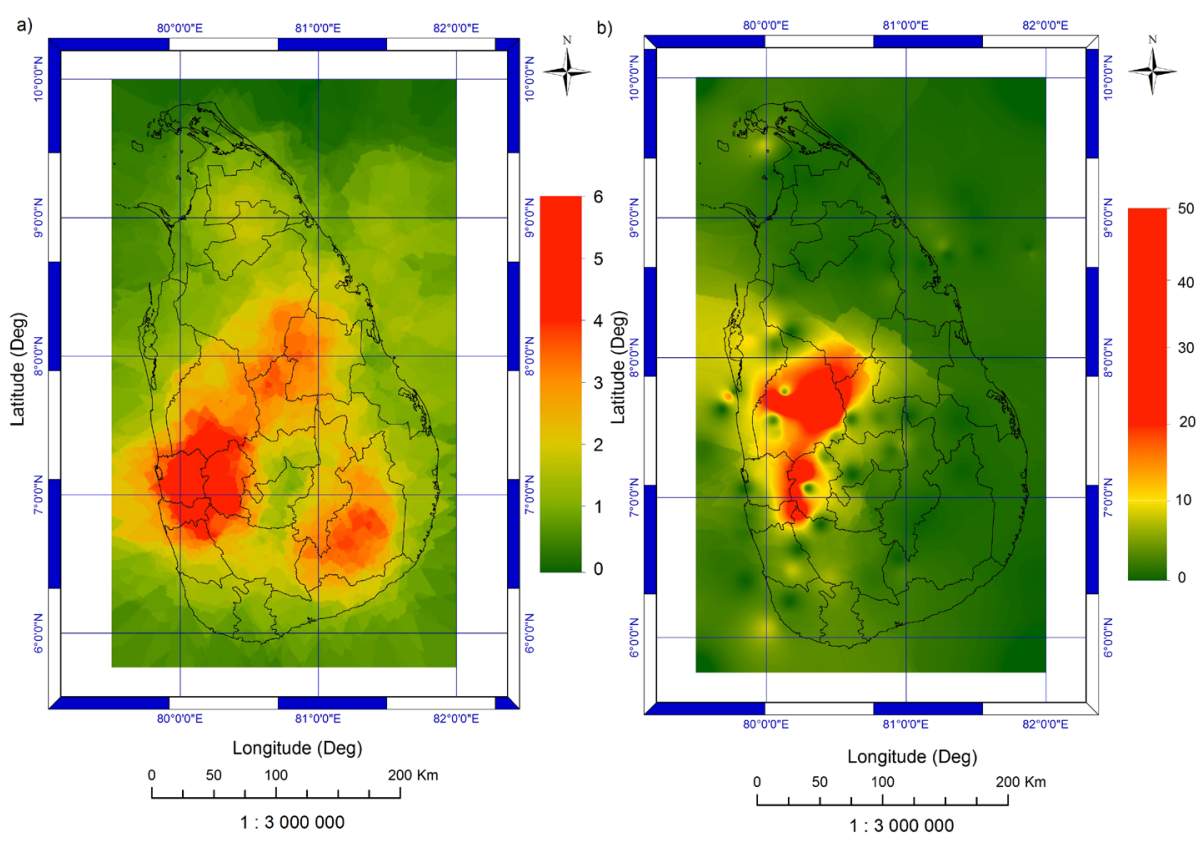

Figure 7. Spatial variation of the lightning flash density in second inter monsoon season over Sri Lanka in the period of 1998-2014 (a) Average spatial variation of the lightning flash density (b) Spatial variation of the lightning flash density in 2006.

\section{Northeast monsoon season (December- February)}

Fig. 8(a) shows the latitudinal variation of average of lightning data in the period of 1998-2014 in northeast monsoon season. Accordingly, the maximum lightning activities occurred around in between the $6.35^{\circ} \mathrm{N}$ and $6.55^{\circ} \mathrm{N}$ and the respective maximum lightning flash density was around 
$1.45 \mathrm{fl} \mathrm{km} \mathrm{kmonth}^{-1}$. In the southern area of the country, lightning activity was increasing with latitude but, in northern area of the country, shows a decreasing trend. Fig. 8(b) shows the zonal average variation of lightning flash density of 17 years in northeast monsoon season. More of the lightning activities had limited to southern area of the country. In 2000 and 2011, patterns of the variation of lightning activities were changed with respected to other years and in year 2000 maximum value of $2.00 \mathrm{fl} \mathrm{km}^{-2}$ month $^{-1}$ was recorded in between $5.95^{\circ} \mathrm{N}$ and $6.15^{0} \mathrm{~N}$. The maximum value of lightning flash density had been increased to $12.5 \%$ relative to the reported details in [11] during the northeast monsoon season. Further, about $76.40 \%$ total lightning activities are increased relative to the reported values in [10]. According to the Fig. $9(\mathrm{a})$, at $6.32^{\circ} \mathrm{N} / 80.13^{\circ} \mathrm{E}$ the maximum lightning flash density was observed which is $8.01 \mathrm{fl} \mathrm{km}^{-2} \mathrm{month}^{-1}$. More lightning activities have concentrated to southwest area of Sri Lanka and Kalutara $\left(6.5854^{\circ} \mathrm{N} / 79.9607^{\circ} \mathrm{E}\right)$ and Galle $\left(6.0535^{\circ} \mathrm{N} / 80.2210^{0} \mathrm{E}\right)$ administrative districts showed more lightning activities. Specially, the climate changes due to the variation of ITCZ over the landmass are associated with the variation pattern of lightning activities. During this period, the ITCZ reaches its northernmost position at $15^{0} \mathrm{~N}$, in January. It reaches about $5^{0} \mathrm{~S}$ and the sun is over head the Tropic of Capricorn. Therefore, winds are originating in the Indian landmass and coming through the Bay of Bengal entering Sri Lanka from northeast between December to February [18]. This convection causes to develop the thunderclouds over the central hills of Sri Lanka during the afternoon and these thunderclouds are pushed to western part of the country. Because of that thunderstorms occur over the western area of the country during evenings. Furthermore, Fig. 9(b) depicts the spatial variation of the lightning flash density with maximum flash density at $6.28^{0} \mathrm{~N} / 80.10^{0} \mathrm{E}$ was $68.06 \mathrm{flkm}^{-2} \mathrm{year}^{-1}$ during the northeast monsoon season in 2000, which had been recorded as the maximum zonal average value.
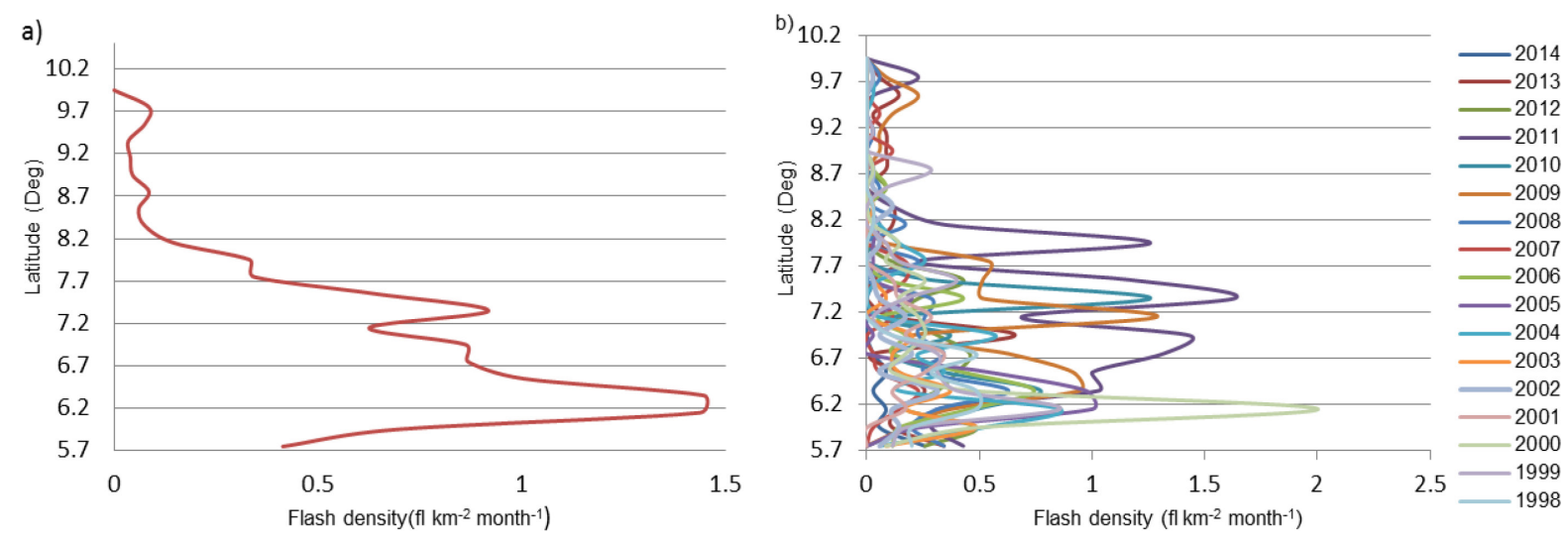

Figure 8. Average variation of flash density in northeast monsoon season over Sri Lanka in the period of 1998-2014 (a) Average latitudinal variation of lightning flash density; (b) Zonal average variation of lightning flash density in year wise. 


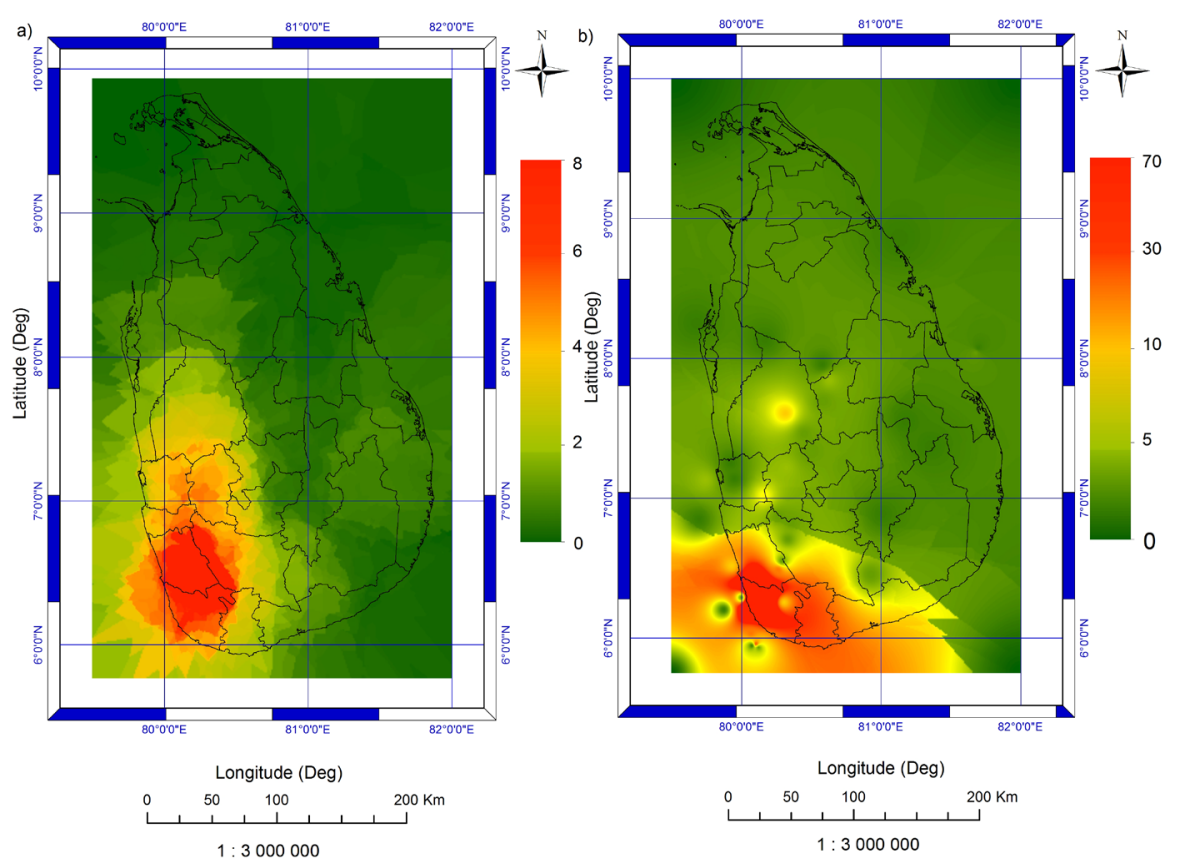

Figure 9. Spatial variation of the lightning flash density in northeast monsoon season over Sri Lanka in the period of 1998-2014 (a) Average spatial variation of the lightning flash density (b) Spatial variation of the lightning flash density in 2000.

The average seasonal variation of the lightning flashes over the country and its surrounded coastal belt is presented in Fig. 10 using flash data from 1998 to 2014. The maximum flash count, $41.67 \%$ had reported in the first inter monsoon season and second maximum flash count had reported in southwest monsoon season with $30.90 \%$ of lightning flashes. However, mean flash count which was normalized to the number of days in a season showed maximum $(53.02 \%)$ in first inter monsoon and second maxima in second inter monsoon season with $24.04 \%$ of lightning flashes. It is confirmed that the most lightning incidents occur in first and second inter monsoon seasons than the other two seasons. Although this result is in agreement with reported details in [10], flash count was increased by $8.57 \%$ during the first inter monsoon season according to the values in [10] and Jayawardana [11] had not reported this value. In the northeast monsoon season, minimum number of lightning activities occurred with $8.51 \%$ of lightning flashes.

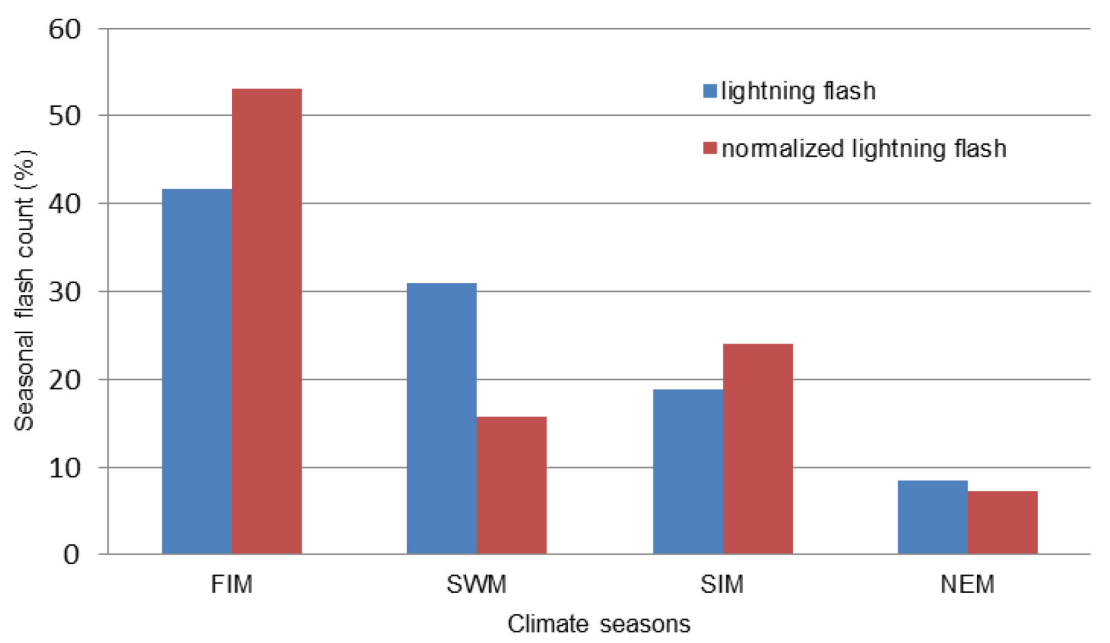

Figure 10. Average of seasonal variation of lightning flash count percentages and it depicts mean flash count parentages which is normalized to the number of days in a season from 1998 to 2014 . (FIM-first inter monsoon, SWM-southwest monsoon, SIM-second inter monsoon and NEMnortheast monsoon). 


\section{Annual variation of lightning flash density}

Fig. 11(a) depicts latitudinal variation of the zonal average of the annual lightning flash density over Sri Lanka and surrounded coastal belt. Maximum flash density of $9.67 \mathrm{fl} \mathrm{km}^{-2} \mathrm{month}^{-1}$ had recorded in the region between $6.95^{\circ} \mathrm{N}$ and $7.15^{\circ} \mathrm{N}$. In between the latitude range of $5.7^{0} \mathrm{~N}$ and $6.7^{0} \mathrm{~N}$, lightning flash density showed continuous increment with latitudes and latitude range of $7.2^{0} \mathrm{~N}$ and $10^{\circ} \mathrm{N}$, showed decrement with some fluctuations. It is similar to variation of the elevation of the country. The zonal average variation of lightning flash density of 17 years is depicted in Fig. 11(b). The maximum value of the $17.94 \mathrm{fl} \mathrm{km}^{-2}$ month $^{-1}$ was recorded in between $6.35^{0} \mathrm{~N}$ and $6.55^{0} \mathrm{~N}$ in 2000 . According to Fig. 11(b), maximum values of zonal average variation of lightning flash density had limited to $6.35^{\circ} \mathrm{N}$ and $7.75^{\circ} \mathrm{N}$ latitude range. Clearly, more of the lightning activities had restricted to southern latitude of the country. Fig. 12(a) illustrates that annual lightning flash density over Sri Lanka and surrounded coastal belt. The maximum annual flash density was about $28.09 \mathrm{fl} \mathrm{km}^{-2}$ year $^{-1}$ at $6.98^{0} \mathrm{~N} / 80.17^{0} \mathrm{E}$. Jayanthiran [10] reported the $7.02 \mathrm{fl} \mathrm{km}^{-2} \mathrm{year}^{-1}$ annual lightning flash density using same satellite data of 1998 to 2006 and the recoded area of maximum activities occurred was changed. Furthermore, the lightning flash density was compared with same satellite data during the period of 1998 to 2012 in [11] and each was assigned to a grid block of $5 \times 5$ $\mathrm{km}^{2}$. It had interpreted annual flash density as $19 \mathrm{fl} \mathrm{km}^{-2}$ year ${ }^{-1}$ at $7.7^{0} \mathrm{~N}, 80.2^{0} \mathrm{E}$ in southwest monsoon period. But, according to this analysis, it had been identified that an increment of $47.36 \%$ in lightning flash density over the county. Furthermore, most of the lightning activities were limited to Gampaha $\left(7.0873^{\circ} \mathrm{N} / 80.0144^{0} \mathrm{E}\right)$, Colombo $\left(6.9271^{0} \mathrm{~N} / 79.8612^{\circ} \mathrm{E}\right)$ and Kegalle $\left(7.2513^{0} \mathrm{~N} / 80.3464^{0} \mathrm{E}\right)$ district of the country and Kalutara $\left(6.5854^{\circ} \mathrm{N} / 79.9607^{\circ} \mathrm{E}\right)$, Ratnapura $\left(6.7056^{\circ} \mathrm{N} / 80.3847^{\circ} \mathrm{E}\right)$ and Kurunagala $\left(7.4730^{\circ} \mathrm{N} / 80.3547^{\circ} \mathrm{E}\right)$ administrative districts have a low influence from lightning activities. Moreover, Fig. 12(b) shows the spatial variation of the lightning flash density in 2011, which had been recorded as the maximum zonal average value. Accordingly, the maximum flash density was about $65.83 \mathrm{fl} \mathrm{km}^{-2} \mathrm{year}^{-1}$ at $7.36^{0} \mathrm{~N} / 80.25^{0} \mathrm{E}$.

According to the Fig. 12(a), there was a noticeable lack of lightning activities in the surrounded coastal belt. Factors affect for this incident can be described as follows. Studies over dynamics of convective systems over the ocean are limited. There is no orographic lifting mechanism over oceanic area; the Sea Surface Temperature (SST) is fairly homogeneous hence pressure gradient is uniform over large oceanic areas in the absence of any synoptic situation, Convective Available Potential Energy (CAPE) over the ocean is relatively weak for severe thunderstorm to occur, convection over ocean is very weak due to low external trigger energy to overcome Convective Inhabitation Energy (CINE), specific heat capacity of the ocean is very high, from rough seas the incident energy is reflected at various angles, some of the incoming energy is absorbed up to the mixed layer depth. These features could lead to significantly lower the lightning flash density at sea areas compared to adjoining land areas [13].
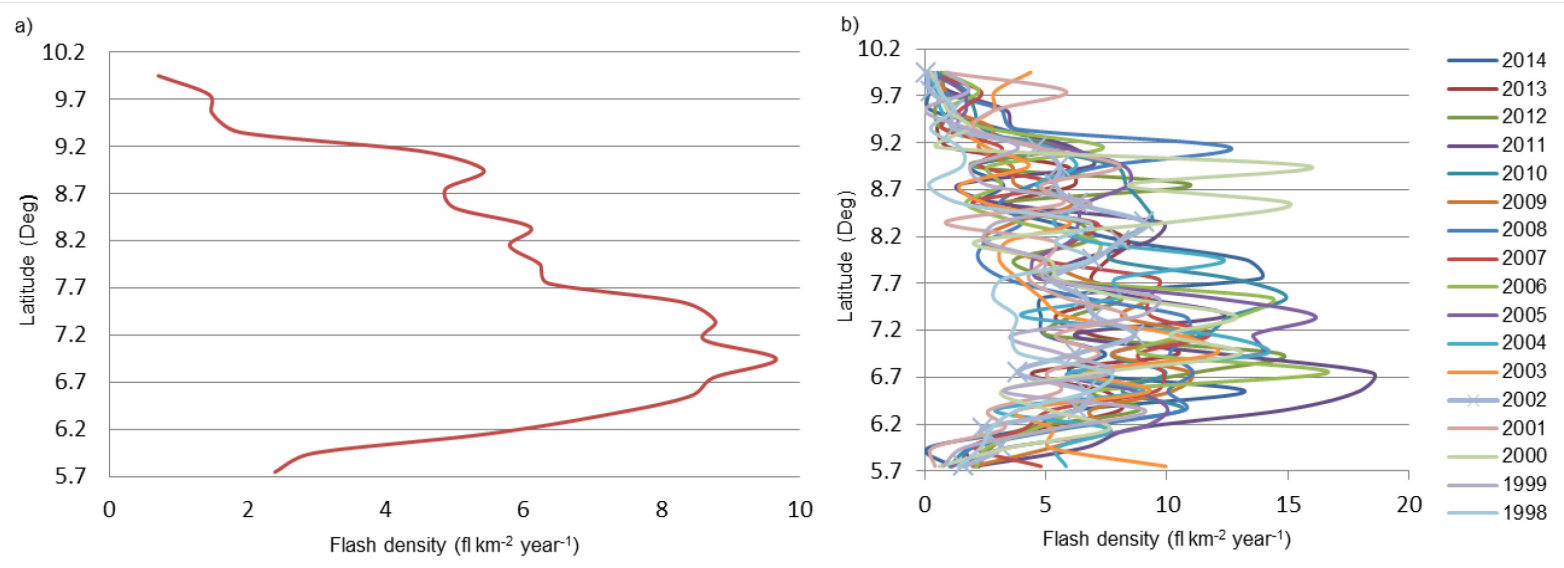

Figure 11. Variation of flash density over Sri Lanka in the period of 1998-2014 (a) Average latitudinal variation of the annual lightning flash density; (b) Zonal variation of flash density over Sri Lanka in year wise. 


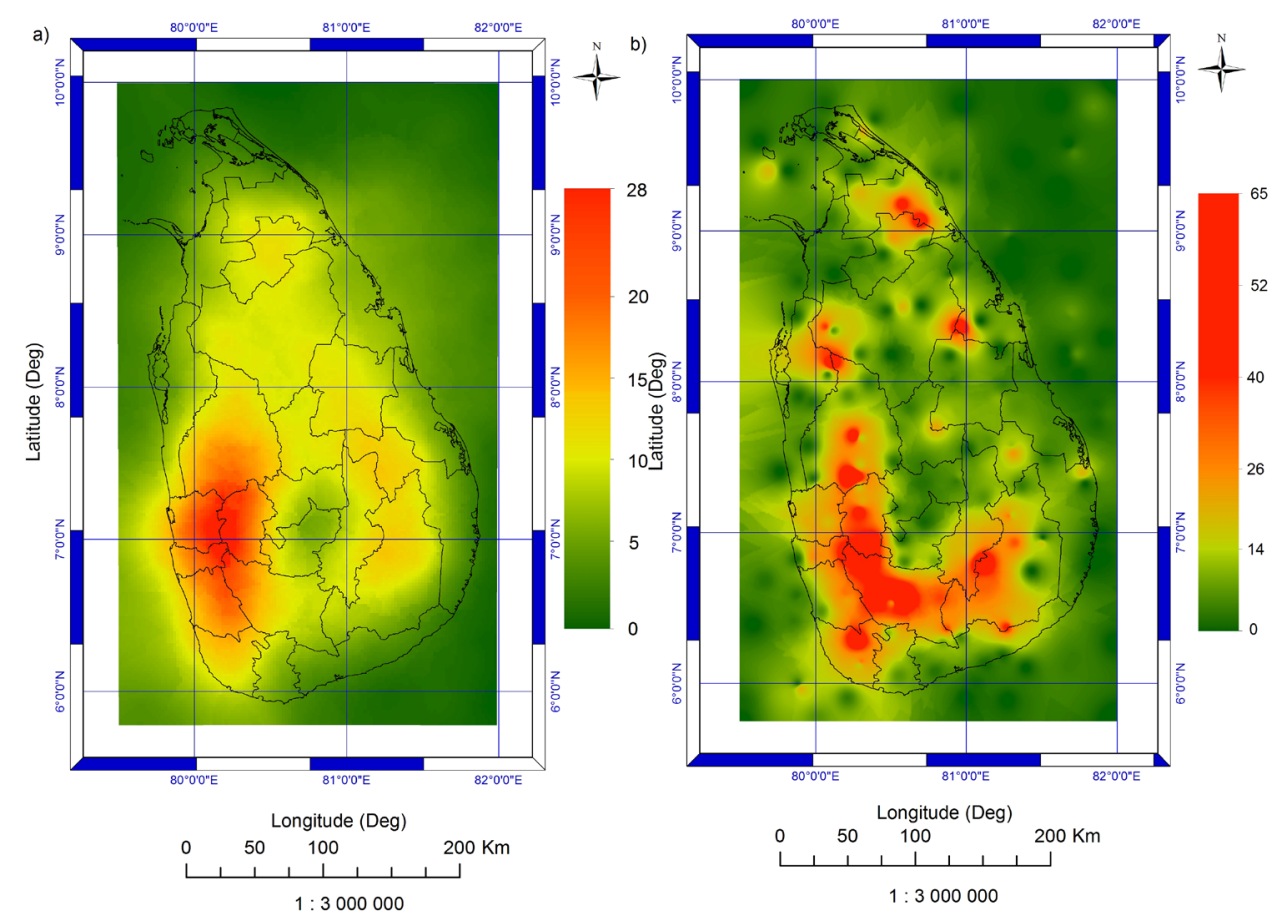

Figure 12. Spatial variation of the annual lightning flash density over Sri Lanka in the period of 19982014 (a) Average spatial variation of the lightning flash density (b) Spatial variation of the lightning flash density in 2011.

The average monthly variation of the lighting activities over the country during a year is depicted in Fig. 13(a). As indicated in Fig. 13(a) the most of the lightning activities occurred in April with $29.12 \%$ of total lightning flashes. In March (12.60\%), May (10.83\%) and October (12.55\%), lightning flash activities were higher than other months. Furthermore, the minimum lightning activities occurred in January with $2.01 \%$. The previously published studies in [10-11] for the maximum lightning activities showed similarity in these months. Fig. 13(b) also illustrates the total number of lightning flashes which occurred during the month of April each year. Fig. 14 shows the percentage of inter annual variation of lightning flash count over Sri Lanka and surrounded coastal belt. In general, according to Fig. 13(b) and 14, number of lightning flashes in April showed a tiny increment over the years for the period considered for the study and month of April in 2012 having the highest occurrence of over 700 flashes. But, in 2003 and 2006 years, lowest lightning activities were recorded for the month of April.
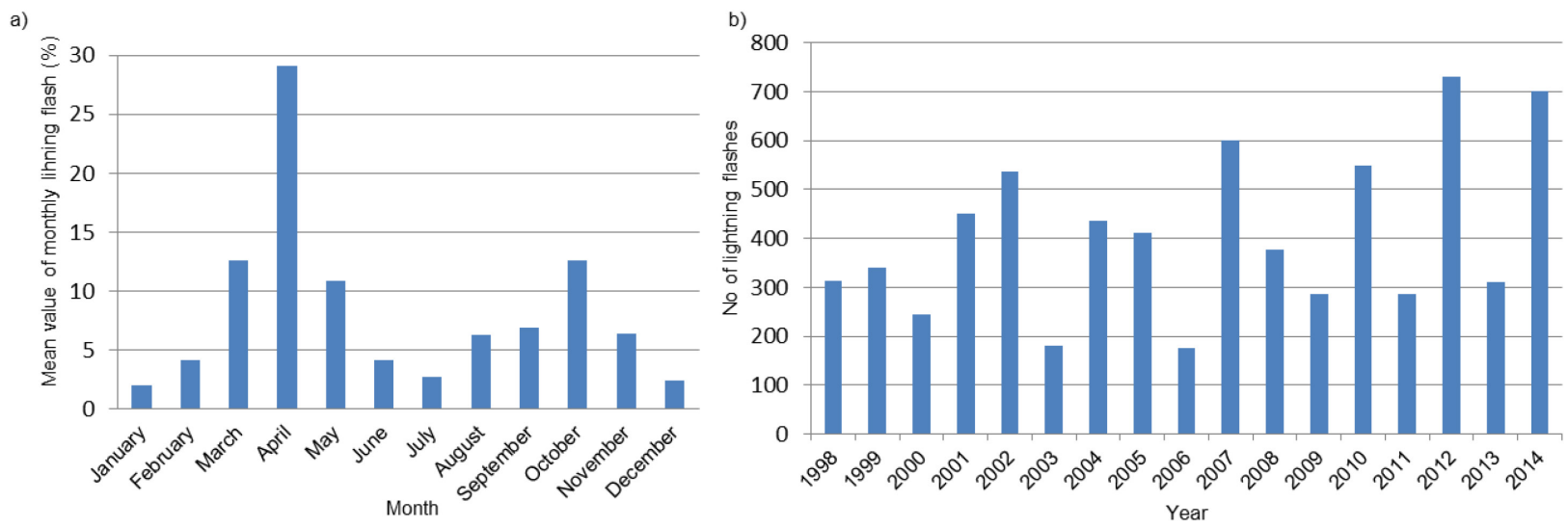

Figure 13. (a) The average monthly variation of the lighting flash activities; (b) Average lightning activities in the month of April in each year over Sri Lanka in the period of 1998 to 2014. 


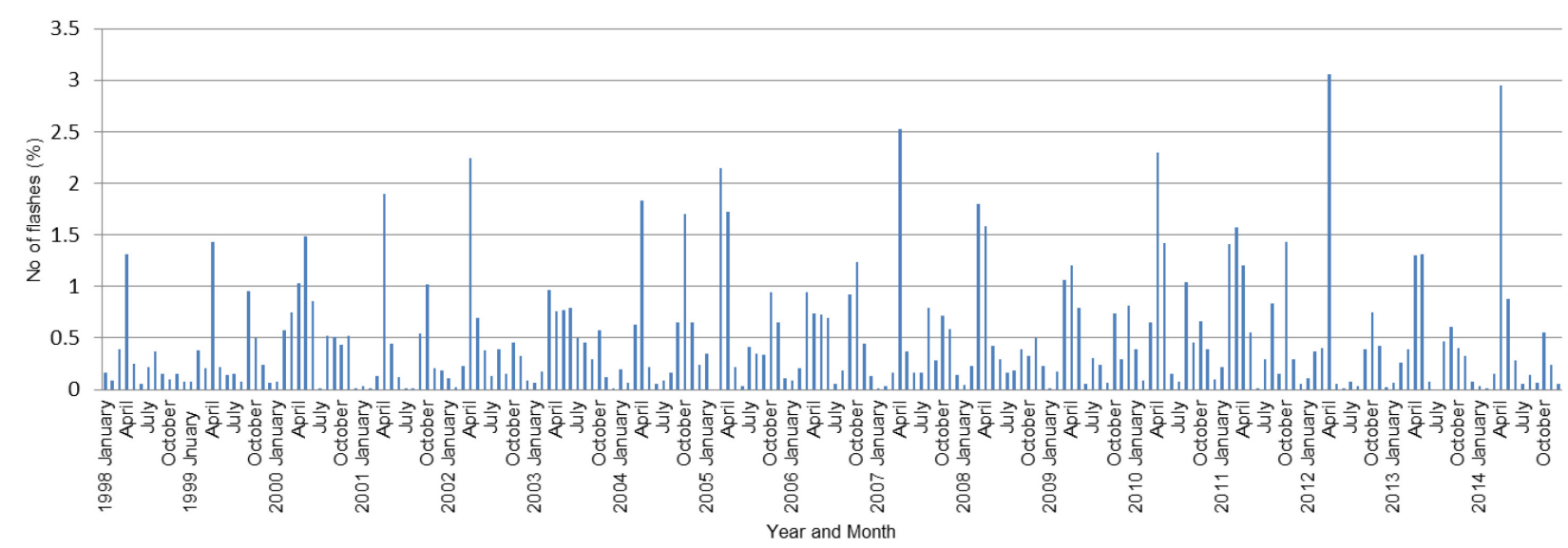

Figure 14. Inter annual variability of lightning flash actives over Sri Lanka in the period of 1998 to 2014.

\section{Conclusions}

The diurnal variation of maximum flash rate was observed at 1530-1630LT (10-11UTC) and minimum was at 0530-0630LT (00-01UTC). But, in some years, time duration which occurred the maximum lightning activities of a day had recorded in the period of 1330-2130LT (08-16UTC). Thus it clearly showed that the maximum thunderstorms activity occurs during late afternoon to evening hours and diurnal temperature variation of the studied particular region is an important parameter of the lightning activities. Seasonal and latitudinal variation of lightning flash density maps showed the maximum occurs in first inter monsoon season with $41.67 \%$ of lightning flashes during the period of 1998 to 2014 . The maximum value of $14 \mathrm{fl} \mathrm{km} \mathrm{kear}^{-1}$ was observed at the $6.98^{0} \mathrm{~N} / 80.16^{0} \mathrm{E}$. In all four seasons considered, the activity was increasing with latitude variation within the southern area of Sri Lanka. But in northern area of the country, the activity was decreasing with latitude variation. The second maximum of lightning flash density which was about $30.90 \%$ of total flashes occurred in southwest monsoon. In this season, maximum flash density was $9.58 \mathrm{fl} \mathrm{km}^{-2} \mathrm{year}^{-1}$, which occurred at $6.78^{0} \mathrm{~N} / 81.33^{0} \mathrm{E}$. However, mean normalized flash count presents that the maximum $(53.02 \%)$ and second maxima $(24.04 \%)$ recorded in first and second inter monsoons respectively. Furthermore, minimum lightning activities $(8.51 \%)$ had recorded in northwest monsoon during the considered time period. It had been seen that, the variation pattern of occurred seasonal lightning activities was in agreement with the propagation of Inter-tropical Conversion Zone (ITCZ) over this region. The maximum annual lightning flash density is $28.09 \mathrm{fl} \mathrm{km}^{-2} \mathrm{year}^{-1}$ occur at $6.98^{0} \mathrm{~N} / 80.17^{0} \mathrm{E}$. Most of the lightning activities were limited to Gampaha $\left(7.0873^{0} \mathrm{~N} / 80.0144^{0} \mathrm{E}\right)$, Colombo $\left(6.9271^{0} \mathrm{~N} / 79.8612^{0} \mathrm{E}\right)$ and Kegalle $\left(7.2513^{\circ} \mathrm{N} / 80.3464^{\circ} \mathrm{E}\right)$ administrative districts of the country. The mean monthly lightning flash counts showed the most of the lightning flashes occurred during March to May with maximum in April having occurrence of $29.12 \%$ flashes and April is the month having a higher temperature. Moreover, number of lightning activities in April showed a tiny increment during the time period of 1998 to 2014. Furthermore, the minimum lightning activities occurred in January with $2.01 \%$ lightning flashes.

\section{Acknowledgement}

The authors are thankful to the Global Hydrology Resource Centre (GHRC), Marshall Space Flight Centre (MSFC), Huntsville, USA for providing the LIS Science data. 


\section{References}

[1] C. Tong, Research and application of active lightning protection technology, 20th Int. Light. Detect. Conf. Tucson, AZ, USA, 2008.

[2] O. Pinto et al., Maximum cloud-to-ground lightning flash densities observed by lightning location systems in the tropical region: A review, Atmos. Res. 84(3) (2007) 189-200.

[3] E. M. Thomson, The dependence of lightning return stroke characteristics on latitude, J. Geophys. Res. 85(C2) (1980) 1050-1056.

[4] J.P. Liyanage et al., Some properties of lightning ground flashes observed in and around Sri Lanka and their seasonal variations, Sri Lankan Journal of Physics. 3 (2002) 75-86.

[5] W.A. Petersen, S.A. Rutledge, On the relationship between cloud-to-ground lightning and convective rainfall, J. Geophys. Res. 103(D12) (1998) 14025.

[6] A. Tapia, J.A. Smith, M. Dixon, Estimation of convective rainfall from lightning observations, Journal of Applied Meteorology. 37(11) (1998) 1497-1509.

[7] TRMM Lightning Imaging Sensor (LIS) Data Sets, NASA. [Online]. Available: https://lightning.nsstc.nasa.gov/data/data_lis.html. Accessed: 05-Jun-2018.

[8] H. J. Christian et al., The Lightning Imaging Sensor, NASA Conf. Publ., 1999, pp. 1-4.

[9] R. Graves et al., A Ten Year Record of Space Based Lightning Measurements, American Geophysical Union, 2009.

[10] V. Jeyanthiran et al., Study of lightning activity over Sri Lanka, in: 29th International Conference on Lightning Protection, Uppsala, Sweden, 2008.

[11] W. Jayawardena, M. Fernando, D.U.J. Sonnadara, Satellite Observation of Lightning Activities Over Sri Lanka, Institute of Physics, Sri Lanka. 30 (2014) 61-66.

[12] R.E. Orville, G.R. Huffines, Lightning ground flash measurements over the Contiguous United States: 1995-97, Mon. Weather Rev. 127(11) (1999) 2693-2703.

[13] H.S. Chaudhari et al., Study of lightning activity over Indian subcontinent, Adv. Geosci. 16 (2010) 121-131.

[14] U.G. Dilaj Maduranga, C. Mahesh Edirisinghe, L. Vimukthi Gamage, Annual variation trend of lightning flash activities over Sri Lanka, World Scientific News. 114 (2018) 256-264.

[15] GHRC: Lightning Imaging Sensor (LIS) Instrument overview. [Online]. Available: https://lightning.nsstc.nasa.gov/lis/overview_lis_instrument.html. Accessed: 05-Jun-2018.

[16] M.W. Maier, A.G. Boulanger, R.I. Sax, Initial assessment of flash density and peak current characteristics of lightning flashes to ground in South Florida, Office of Standards Development, U.S. Nuclear Regularity Commission, Washington, 43 pp. NUREG/CR-1024, 1979.

[17] C.H. Sui et al., Diurnal variations in tropical oceanic cumulus convection during TOGA COARE, J. Atmos. Sci. 54(5) (1997) 639-655.

[18] I.P. Wasana, Exploring the spatial and temporal variations in Sri Lanka, MPhil. Thesis, University of Colombo, Sri Lanka, 2003. 